Tropical Journal of Pharmaceutical Research October 2011; 10 (5): 681-692

(C) Pharmacotherapy Group,

Faculty of Pharmacy, University of Benin

Benin City, 300001 Nigeria.

All rights reserved.

Available online at http://www.tjpr.org

Review Article

http://dx.doi.org/10.4314/tjpr.v10i5.18

\title{
Phytochemical Constituents and Pharmacological Activities of Plants from the Genus Adiantum: A Review
}

\author{
C Pan ${ }^{1}$, YG Chen ${ }^{1 *}, \mathrm{XY} \mathrm{Ma}^{1}, \mathrm{JH}^{\mathrm{Jiang}}{ }^{1}, \mathrm{~F} \mathrm{He}^{1}$ and $\mathrm{Y} \mathrm{Zhang}^{2}$
}

${ }^{1}$ Department of Chemistry, Yunnan Normal University, Kunming 650500, ${ }^{2}$ School of Pharmacy, Kunming Medical College, Kunming 650031, China.

\begin{abstract}
Adiantum is a genus of ca. 200 species in the family Adiantaceae, distributed extensively across the world from cool temperate zones to hot tropical regions. A lot of Adiantum species have been used in traditional Chinese medicine to cure human and animal diseases including relief of internal heat or fever, enhancement of urination, removal of urinary calculus, and sundry other curative claims. Chemical studies have shown the presence of various classes of compounds, the main ones being triterpenoids, flavonoids, phenyl propanoids, steroids, alicyclic acids, lipids and long-chain compounds. The extract of this genus as well as pure compounds isolated from it have been demonstrated to possess multiple pharmacological activities such as analgesic, antinociceptive, anti-implantation, and antimicrobial activities. In this review, we have addressed the phytochemistry and pharmacological activities of the Adiantum species in order to collate existing information on this plant as well as highlight its multi-activity properties as a medicinal agent.
\end{abstract}

Keywords: Adiantum species, Adiantaceae, Phytochemical constituents, Pharmacological activities. 


\section{INTRODUCTION}

Adiantum is a genus of ca. 200 species in the family Adiantaceae, distributed extensively over the world from cool temperate zones to hot tropical regions. As many as 30 species and 5 varieties are found in China [1]. Half of the species have been used in traditional Chinese medicine to cure human and animal diseases including relief of internal heat or fever, enhancement of urination, removal of urinary calculus, elimination of stasis to resolve swelling, relief of cough, cure of diarrhea and stoppage of bleeding, as well as treatment of urinary tract infection, calculus, hepatitis, hemorrhage, fractures, snakebite, burns and scald [2].

According to the literature, Adiantum species are a rich source of triterpenes with various structural skeletons. Besides, flavonoids, phenyl propanoids and sterols have been isolated from the genus Adiantum [3-14]. These compounds have been reported to show various bioactivities, such as analgesic, antinociceptive, anti-implantation, and antimicrobial activities. In this review, we summarize the current knowledge of the phytochemistry of the plants as well as the compounds that have been isolated from the genus Adiantum. The biological activities of this genus have also been addressed.

\section{PHYTOCHEMISTRY}

Since the 1960s, 124 compounds, including terpenoids, flavonoids, phenyl propanoids, steroids, alicyclic acids, lipids and long-chain compounds have been reportedly isolated from the genus. Triterpenoids and flavonoids are the dominant constituents within the genus Adiantum.

\section{Terpenoids}

Eighty-five triterpenoids were isolated from the genus Adiantum [3-5,15-52]. Most of the triterpenoids are pentacyclic and belong to the hopane and migrated hopane or closely related groups such as isohopane, neohopene, fernane, isofernene, filicane, pteronane and adiane types. The presence of a large number of the nor-compounds is also a characteristic feature of this genus. Hopane-type triterpenoids, 1-9, were isolated from various Adiantum species, such as $A$. capillus-veneri, $A$. edgeworthii, $A$. monochlamys, $A$. caudatum, $A$. incisum, $A$. cuneatum, $A$. pedatum, $A$. tetraphyllum and A. lunulactum (syn. A. philippense) (Table 1, Figure 1) [3,15-26]. Isohopane-type triterpenoid, 10, was isolated from $A$. lunulatum [27], and neohopane-type triterpenoids, 11-16 were also isolated from the genus Adiantum (Table 2, Figure 2).

Other migrated hopane or closely related triterpenoids isolated from the genus Adiantum include norhopane-type triterpenoids, 17-29 (Table 3, Figure 3), fernane-type triterpenoids, 30-51 (Table 4, Figure 4), an isofernane-type triterpenoid, isofernene (52) isolated from $A$. monochlamys and $A$. pedatum $[19,40]$, adiane-type triterpenoids, 53-57, and filicanetype triterpenoids, 58-67 (Table 5, Figure 5), and a pteronane-type triterpenoid, pteron-14en- $7 \alpha$-ol obtained from A.capillus-veneris [16]. Secofilicanes 66 and 67 isolated from $A$. cuneatum are the first two secotriterpenoids that have been reported in ferns. Adipedatol (28) and filicenal (61) are the first two examples of the natural triterpenoids having the hemiketal and the conjugated aldehyde groups, respectively $[23,28,35,40]$.

Other pentacyclics include lupane and norlupane triterpenoids lup-20(29)-en-28-ol, 24-norlupan-3-one and adiantulupanone isolated from $A$. capillus-veneris, $A$. tetraphyllum and $A$. venustum $[3,47,48]$. Oleanane triterpenoids olean-12-en-3-one and olean-18-en-3-one were isolated from $A$. capillus-veneris $\quad[15,25]$. Noroleanane triterpenoids adininaonol and adiantuoleanone were isolated from $A$. venustum and $A$. incisum respectively [21,48]. Ursane triterpenoid urs-20-en-16-ol was isolated from $A$. capillus-veneris [47], and gammacerane triterpenoids tetrahyma- 
Table 1: Hopane-type triterpenoids from the genus Adiantum

\begin{tabular}{|c|c|c|c|}
\hline No. & Compound name & Source* & Ref. \\
\hline 1 & Hop-22(29)-ene (= Diploptene) & $\mathrm{A} 1 \sim \mathrm{A} 3$ & $15-19$ \\
\hline 2 & $17 \beta, 21 \beta$-Epoxyhopane & A4 & 20 \\
\hline 3 & Adininaneone & A5 & 21 \\
\hline 4 & Hydroxyhopane (= Hopanol) & $A 1, A 2, A 6 \sim A 8$ & $3,15-17,22,23$ \\
\hline 5 & Mollugogenol A & A9 & 24 \\
\hline 6 & $6 \alpha$-Acetoxy-16ß,22-dihydroxy-3-ketoisohopane & $\mathrm{A} 1, \mathrm{~A} 9$ & 24,25 \\
\hline 7 & 17,29-Epoxyhopane & $\mathrm{A} 1$ & 16 \\
\hline 8 & Hopan-28,22-olide & A1 & 16 \\
\hline 9 & $3 \beta$-Acetoxy-6$\alpha$-hydroxy-hop-15,17(21)-diene & A9 & 26 \\
\hline
\end{tabular}

${ }^{*} A 1=A$. capillus-veneris, $A 2=A$. edgeworthii, $A 3=A$. monochlamys, $A 4=A$. caudatum, $A 5=A$. incisum, $A 6=$ A. cuneatum, $A 7=A$. pedatum, $A 8=A$. tetraphyllum, $A 9=A$. lunulatum

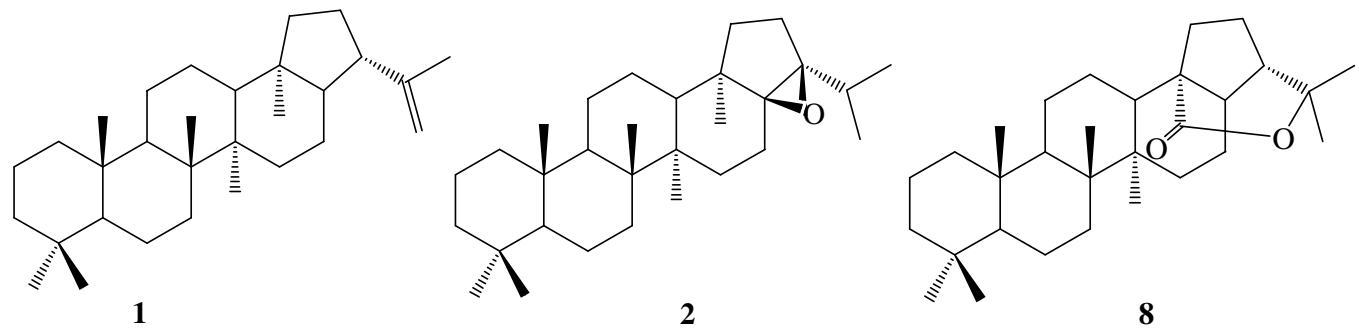

Figure 1: Selected hopane-type triterpenoids from the Genus Adiantum

Table 2: Isohopane and neohopane-type triterpenoids from the Genus Adiantum

\begin{tabular}{lllc}
\hline No. & \multicolumn{1}{c}{ Compound name } & Source $^{*}$ & Ref. \\
\hline $\mathbf{1 0}$ & $3 \beta$-Acetoxy-21 $\alpha \mathrm{H}$-hop-22(29)-ene & A9 & 27 \\
$\mathbf{1 1}$ & Neohop-12-ene (=Neohopene) & A1 A3,A6,A7 & $15-18,23,28,29$ \\
$\mathbf{1 2}$ & Neohop-18-en-12 $\alpha$-ol & A6 & 30 \\
$\mathbf{1 3}$ & 13-Epineohop-18-en-12 $\alpha$-ol & A6 & 30 \\
$\mathbf{1 4}$ & Neohop-13(18)-ene & A3,A4,A7 & $18,20,23,29$ \\
$\mathbf{1 5}$ & Neohop-13(18)-en-19 $\alpha$-ol & A6 & 30 \\
$\mathbf{1 6}$ & Neohopa-11,13(18)-diene & A3,A6,A7 & $18,23,28,29$ \\
\hline
\end{tabular}

${ }^{*} A 1=A$. capillus-veneris, $A 2=A$. edgeworthii, $A 3=A$. monochlamys, $A 4=A$. caudatum, $A 6=A$. cuneatum, $A 7=A$. pedatum, $A 9=A$. lunulatum

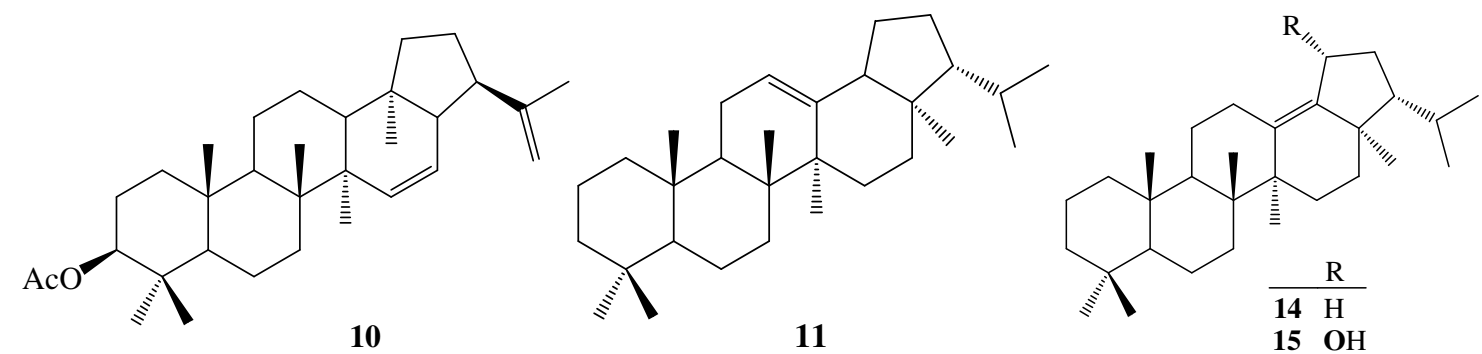

Fig 2: Selected isohopane and neohopane-type triterpenoids from the Genus Adiantum 
Table 3: Norhopane-type triterpenoids from the genus Adiantum

\begin{tabular}{|c|c|c|c|}
\hline No. & Compound name & Source* & Ref. \\
\hline 17 & Trisnorhopane & $\mathrm{A} 1, \mathrm{~A} 6$ & 16,28 \\
\hline 18 & $\begin{array}{l}\text { Isoglaucanone } \\
\text { (= 17 } \alpha \mathrm{H} \text {-Trisnorhopan-21-one) }\end{array}$ & $\mathrm{A} 1, \mathrm{~A} 6, \mathrm{~A} 7$ & $15,16,23,28$ \\
\hline 19 & Glaucanol A & A7 & 23 \\
\hline 20 & Glaucanol B acetate & A6 & 28 \\
\hline 21 & $\begin{array}{l}\text { 21-Hydroxy-30-norhopan-22-one } \\
\text { (= } 21 \text {-Hydroxyadiantone, } \\
\text { Hydroxyadiantone) }\end{array}$ & $\mathrm{A} 1, \mathrm{~A} 3, \mathrm{~A} 6, \mathrm{~A} 7, \mathrm{~A} 10, \mathrm{~A} 11$ & $15,16,18,23,28,31-33$ \\
\hline 22 & Isoadiantone & $\mathrm{A} 1, \mathrm{~A} 3 \sim \mathrm{A} 7, \mathrm{~A} 12$ & $15,16,18,20,21,23,28,33-38$ \\
\hline 23 & Adiantone & $\mathrm{A} 1 \sim \mathrm{A} 7, \mathrm{~A} 9, \mathrm{~A} 10, \mathrm{~A} 13$ & $\begin{array}{c}4,5,15-18,20,21,23,28,31 \\
36,37,39-41\end{array}$ \\
\hline 24 & $19 \alpha$-Hydroxyadiantone & $\mathrm{A} 2, \mathrm{~A} 4$ & 17,20 \\
\hline 25 & 29-Norhopan-22-ol & A4 & 4 \\
\hline 26 & $\begin{array}{l}\text { Isoadiantol B [= (22S)-30- } \\
\text { Norisohopan-22-ol, Isoadiantol] }\end{array}$ & $\mathrm{A} 1, \mathrm{~A} 3, \mathrm{~A} 6, \mathrm{~A} 7, \mathrm{~A} 11$ & $15,18,22,23,32$ \\
\hline 27 & 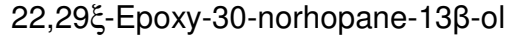 & A9 & 39 \\
\hline 28 & Adipedatol & A7 & 23,40 \\
\hline 29 & Adipedatol Me ether & A7 & 40 \\
\hline
\end{tabular}

nol, epihakonanediol, ketohakonanol (= oxohakonanol) and hakonanediol were isolated from $A$. monochlamys [18]. Tetrahymanol and ketohakonanol were also isolated from $A$. capillus-veneris, $A$. pedatum, $A$. emarginatum, $A$. cuneatum and $A$. incisum $[22,23,32,33,49]$.

Besides, tetracyclic triterpenoids have been isolated from $A$. venustum, including lanostane triterpenoids adiantulanosterol, lanost-20(22)-en-3,19-ether and adiantulanostene, as well as tirucallane triterpenes adiantutirucallenes A and B [48, 50-52].

Diterpenoids, 8,13-epoxy-14-labden-19-oic acid has been isolated from $A$. emarginatum [32], and linear diterpenoids phytol and phyten-3(20)-1,2-diol were isolated from $A$. tetraphyllum [3]. Only one tetraterpenoid, $\alpha$ carotene monoepoxide was isolated from $A$. venustum [5].

\section{Flavonoids}

Flavonoids (18 of them) have been isolated from the genus Adiantum [3-14]. Quercetin, keampferol and their glycosides are the most common flavonols. Quercetin was isolated from $A$. tetraphyllum [3] while hyperin and trifolin have been isolated from $A$. monochlamys and $A$. malesianum respectively [6,9]. Quercetin 3-O-(6"malonyl)-D-galactoside, rutin, isoquercetin, querciturone, kaempferol 3-glucuronide, astragalin, keampferol 3-sulphate, kaempferol 3,7-diglucoside, nicotiflorin and kaempferol 3-O-rutinoside sulfate were isolated from $A$. capillus-veneris $[7,8,10,12,13]$. Querciturone and kaempferol 3-glucuronide were also isolated from $A$. cuneatum [7]. Isoquercetin has also isolated from $A$. monochlamys, $A$. caudatum, $A$. tetraphyllum, $A$. venustum and $A$. aethiopicum [3-6] while astragalin was isolated from $A$. monochlamys, $A$. cuneatum, $A$. venustum and $A$. aethiopicum $[5,6,11]$.

Flavanone prunin was obtained from $A$. monochlamys and $A$. aethiopicum respectively [6]. Flavandiol, leucopelargonidin was isolated from $A$. venustum [5]. 2',4',6'Trihydroxychalcone were isolated from $A$. sulphureum [14]. Flavone $C$-glucosides vitexin and isovitexin were isolated from $A$. malesianum [9]. 


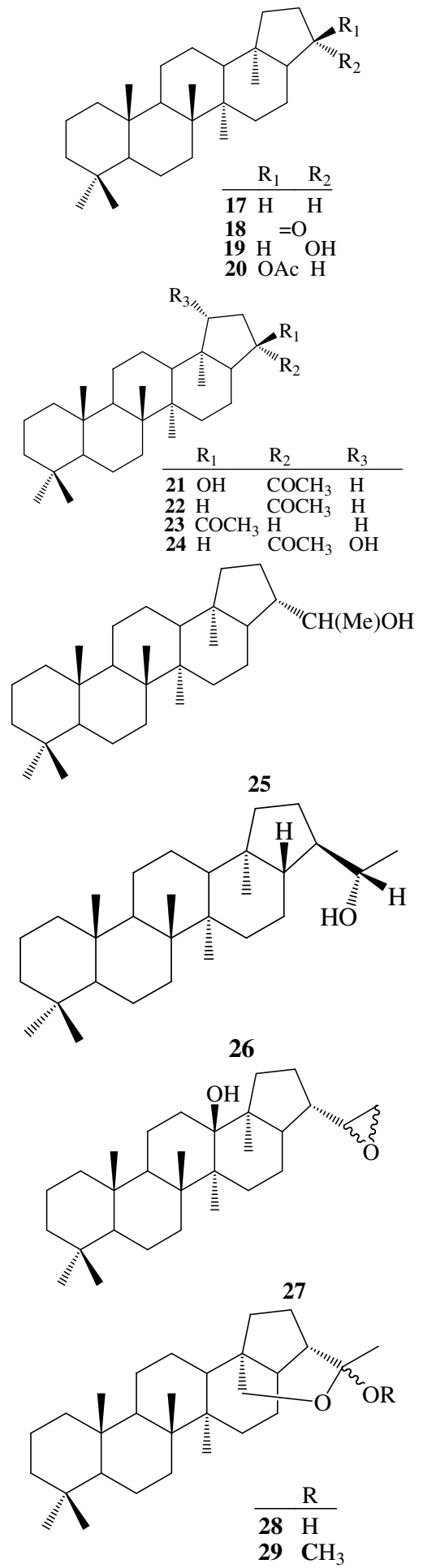

Figure 3: Selected norhopane-type triterpenoids from the genus Adiantum

\section{Phenyl propanoids}

Phenyl propanoids, 1-p-coumarylglucose 6sulphate, I-p-coumarylglucose 2-sulphate, Icaffeylglucose 3-sulphate, 1-caffeylgalactose 6-sulphate and 1-caffeylglucose were isolated from $A$. capillus-veneris $[8,53]$ whereas 1-p-coumarylglucose 6-sulphate was also obtained from $A$. pulverulentum [54]. Coumarins methyl-p-coumarate and psoralen were isolated from $A$. thalictroides var hirsutum [4]. A coumarin dimmer, daphnoretin was isolated from $A$. capillusveneris [55].

\section{Steroids}

$\beta$-Sitosterol has been isolated from $A$. capillus-veneris, $A$. caudatum, $A$. tetraphyllum and $A$. thalictroides var hirsutum $[3,4,36,40,56]$, daucosterol from $A$. caudatum [4], and stigmasterol and campesterol from $A$. capillus-veneris [56].

\section{Alicyclic acids}

Alicyclic acids, shikimic acid and quinic acid were isolated from $A$. capillus-veneris [57].

\section{Lipids}

The betaine lipid diacylglyceryl-O-4'-(N,N,N,-trimethyl)homoserine was isolated from $A$. capillus-veneris [58]. Positional analysis of the fatty acids by lipase treatment showed that palmitic acid is esterified at position 1, and linoleic, linolenic, and arachidonic acids at position 2 of the glycerol moiety of the lipid. Although the trimethylhomoserine lipid has been found in some algal species, this is the first report that it exists in a vascular plant [58].

\section{Other long-chain compounds}

16-hentriacontanone and hentriacontane were isolated from $A$. caudatum [36]. Besides, arachidonic acid was found in $A$. pedatum[59]. The essential oil in the roots of $A$. flabellulatum contained $n$-decanoic acid 
Table 4: Fernane-type triterpenoids from the genus Adiantum

\begin{tabular}{|c|c|c|c|}
\hline No. & Compound name & Source $^{*}$ & Ref. \\
\hline 30 & Fern-9(11)-en-28-ol & $\mathrm{A} 1, \mathrm{~A} 4, \mathrm{~A} 9$ & $15,16,20,39$ \\
\hline 31 & Fern-9(11)-en-25-oic acid & $\mathrm{A} 2, \mathrm{~A} 9, \mathrm{~A} 10$ & $17,39,42$ \\
\hline 32 & Fern-9(11)-en-25-ol & A6 & 30 \\
\hline 33 & Fern-9(11)-en-6 $\alpha$-ol & A9 & 39 \\
\hline 34 & Fern-9(11)-en-3 $\alpha$-ol & A1 & 16 \\
\hline 35 & Fern-9(11)-en-12ß-ol & A1 & 15 \\
\hline 36 & Fern-9(11)-en-12-one & A1 & 15,16 \\
\hline 37 & $\begin{array}{l}\text { Fern-9(11)-ene (= Fernene, } \\
\text { Davallene) }\end{array}$ & $\mathrm{A} 1 \sim \mathrm{A} 4, \mathrm{~A} 6, \mathrm{~A} 7, \mathrm{~A} 9$ & $\begin{array}{c}15-18,20,23,28,37 \\
39,40,43\end{array}$ \\
\hline 38 & $19 \alpha$-Hydroxyfern-9(11)-ene & A4 & 20 \\
\hline 39 & 23-Hydroxyfernene & $\mathrm{A} 5, \mathrm{~A} 7$ & 21,23 \\
\hline 40 & Fern-7-en-3a-ol & $\mathrm{A} 1$ & 16 \\
\hline 41 & Fern-7-en-25-ol & A6 & 30 \\
\hline 42 & Fern-7-ene $=7$-fernene & $\mathrm{A} 1 \sim \mathrm{A} 4, \mathrm{~A} 6, \mathrm{~A} 7$ & $15-20,23,28,40$ \\
\hline 43 & $19 \alpha$-Hydroxyfern-7-ene & A4 & 20 \\
\hline 44 & 25-Norfern-7-en-10 3 -yl formate & A6 & 28 \\
\hline 45 & Ferna-7,9(11)-diene & $\mathrm{A} 1, \mathrm{~A} 3, \mathrm{~A} 4, \mathrm{~A} 7$ & $15,16,18,20,23,29$ \\
\hline 46 & $19 \alpha$-Hydroxyferna-7,9(11)-diene & A4 & 20 \\
\hline 47 & Fern-8-ene & $\mathrm{A} 3, \mathrm{~A} 4, \mathrm{~A} 7$ & $18,20,23$ \\
\hline 48 & $7 \alpha, 8 \alpha$-Epoxyfernan-25-ol & A6 & 22,44 \\
\hline 49 & $7 \beta, 25$-Epoxyfern-8-ene & A6 & 28 \\
\hline 50 & 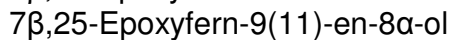 & A6 & 22,43 \\
\hline 51 & $8 \alpha$-Hydroxyfernan-25,7 3 -olide & A4 & 20 \\
\hline
\end{tabular}
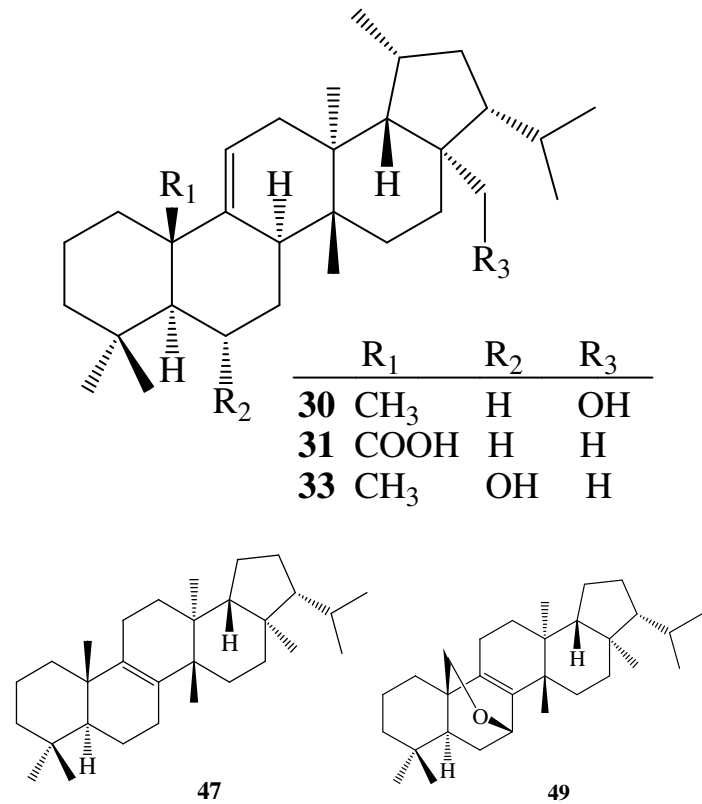

Figure 4: Selected fernane-type triterpenoids from the genus Adiantum
(11.44\%), 6,10,14-trimethyl-2-pentadecanone $(11.23 \%)$, and nonanoic acid (6.15\%), whereas the essential oil in the leaves of $A$. flabellulatum contained $n$-decanoic acid $(11.77 \%)$ and nonanoic acid $(4.01 \%)$ [60]. The essential oil from the leaves of $A$. edgeworthii contained $n$-nonanal as the chief constituent [61].

\section{Other constituents}

A saponin glycoside was isolated from $A$. capillus-veneris. Study of the hydrolytic products of the saponin revealed a triterpenoid hydroxyhopanone aglycon and the sugar components: galactose, xylose and rhamnose. $A$. capillus-veneris was also contained protein [62]. The essential oil in the roots of $A$. flabellulatum contained diethyl phthalate [60]. The essential oil in the leaves of $A$. flabellulatum contained 2-isopropenyl4a,8-dimethyl-1,2,3,4,4a,5,6,7-octahydrona- 
Table 5: Adiane and filicane-type triterpenoids from the genus Adiantum

\begin{tabular}{|c|c|c|c|}
\hline No. & Compound name & Source $^{*}$ & Ref. \\
\hline 53 & Adian-5-en-3 $\alpha$-ol (=Adiantol) & $\mathrm{A} 1, \mathrm{~A} 6$ & 16,35 \\
\hline 54 & Adian-5-ene (=Adianene) & $\mathrm{A} 1$ & 16 \\
\hline 55 & Adian-5-en-25-ol & A6 & 30 \\
\hline 56 & Adian-5(10)-en-3 $\alpha$-ol & $\mathrm{A} 1$ & 16 \\
\hline 57 & $\begin{array}{l}\text { Adianene ozonide (= Adian-5-ene } \\
\text { ozonide) }\end{array}$ & A3 & 18,45 \\
\hline 58 & Filic-3-ene (= 3-Filicene, Filicene) & $\mathrm{A} 1 \sim \mathrm{A} 4, \mathrm{~A} 6, \mathrm{~A} 7, \mathrm{~A} 10$ & $4,5,15-20,23,28,32,40$ \\
\hline 59 & Filicenol A & A3 & 18 \\
\hline 60 & Filicenol B & A3,A9 & 18,39 \\
\hline 61 & Filicenal & A6,A7 & $23,28,35,40$ \\
\hline 62 & Filicenoic acid & A7 & 23 \\
\hline 63 & $4 \alpha$-Hydroxyfilican-3-one & A1 & 15 \\
\hline 64 & $3 \alpha-H y d r o x y-4 \alpha-m e t h o x y f i l i c a n e$ & A4 & 20 \\
\hline 65 & $\begin{array}{l}\text { Adiantoxide }= \\
3 \alpha, 4 \alpha \text {-Epoxyfilicane }\end{array}$ & A1 & $15,16,46$ \\
\hline 66 & $\begin{array}{l}\text { 4,23-Bisnor-3,4-secofilic-5(24)- } \\
\text { en-3-al }\end{array}$ & A6 & 22,44 \\
\hline 67 & $\begin{array}{l}\text { 4,23-Bisnor-3,3-dimethoxy-3,4- } \\
\text { secofilic-5(24)-ene }\end{array}$ & A6 & 22,44 \\
\hline \multicolumn{4}{|c|}{$\begin{array}{l}A 1=A . \text { capillus-veneris, } A 2=A . \text { edgeworthii, } A 3=A . \text { monochlamys, } A 4=A . \text { caudatum, } A 6=A . \\
\text { cuneatum, } A 7=A . \text { pedatum }\end{array}$} \\
\hline
\end{tabular}

Figure 5: Selected adiane and filicane-type triterpenoids from the genus Adiantum

phthalene $\quad(10.63 \%), \quad[1 R-(1 \alpha, 7 \beta, 8 \mathrm{a} \alpha)]-$ 1,2,3,5,6,7,8,8a-octahydro-1,8a-dimethyl-7(1-methylethenyl)-naphthalene $(9.88 \%), \alpha-$ panasinsen $(8.11 \%)$, 4-tetradecyne $(6.63 \%)$, and $\beta$-pinene (5.16\%) [60]. The essential oil from the roots of $A$. edgeworthii contained 2,6-di-tert-butyl p-cresol as the chief constituent [61].

\section{PHARMACOLOGICAL ACTIVITIES}

The extract of the Adiantum species as well as pure compounds isolated from them, have been demonstrated to possess multiple pharmacological activities including analgesic, antinociceptive, anti-implantation, and antimicrobial activities.

\section{Analgesic activity}

Hexane fraction from $A$. cuneatum as well as filicene (58) and filicenal (61), given intraperitoneally, exhibited potent analgesic activity when evaluated in two models of pain in mice - writhing test and formalin-induced pain. 58 presented an $I D_{50}$ value of 19.5 
$\mu \mathrm{mol} / \mathrm{kg}$ body weight (writhing test), being about 7-fold more active than some reference drugs, such as acetyl salicylic acid and acetaminophen, with the dose of 73.0-247.0, and $140-250 \mu \mathrm{mol} / \mathrm{kg}$ respectively. It also inhibited both phases (neurogenic and inflammatory) of the formalin test at $10 \mathrm{mg} / \mathrm{kg}$ $(24 \mu \mathrm{mol} / \mathrm{kg})$. The results confirm and justify the popular use of this plant for the treatment of sorrowful conditions [35]. Ethanol extract of A. venustum demonstrated good analgesic activity with $100 \mathrm{mg} / \mathrm{kg}$ when compared with $50 \mathrm{mg} / \mathrm{kg}$ [63].

\section{Anti-inflammatory activity}

The chronic anti-inflammatory activity of the ethanol extract of $A$. venustum has been evaluated by carrageen-induced paw edema method. The results, at the two dose levels tested in rats, indicate significant antiinflammatory activity. Maximum inhibition of inflammation was $71.15 \%$ recorded with 100 $\mathrm{mg} / \mathrm{kg}$ of plant extract. A further decrease in dose level $(50 \mathrm{mg} / \mathrm{kg})$ produced an even greater decrease in anti-inflammatory activity [63].

\section{Antinociceptive activity}

When evaluated against acetic acid-induced abdominal constrictions, filicene (58) $(10,30$ and $60 \mathrm{mg} / \mathrm{kg}$, i.p.) produced dose-related inhibition of the number of constrictions, being several times more potent, with $I_{50}$ of $9.17 \mathrm{mg} / \mathrm{kg}(6.27-13.18 \mathrm{mg} / \mathrm{kg})$, than acetaminophen which had an $\mathrm{ID}_{50}$ of 18.8 $\mathrm{mg} / \mathrm{kg}$ (15.7 - $22.6 \mathrm{mg} / \mathrm{kg})$, diclofenac $\left(\mathrm{ID}_{50}\right.$ 12.1, range 9.40-15.6 $\mathrm{mg} / \mathrm{kg}$ ) and acetylsalicylic acid $\left(\mathrm{ID}_{50} 24.0\right.$, range 13.1-43.8 $\mathrm{mg} / \mathrm{kg}$ ); the dose was the same as those used for the standard drugs. 58 also produced dose-related inhibition of the pain caused by capsaicin and glutamate, with mean $I D_{50}$ values of 11.7 (range 8.51 - 16.0) and $<10 \mathrm{mg} / \mathrm{kg}$, respectively. Its antinociceptive action was significantly reversed by atropine, haloperidol, GABAA and GABAB antagonists (bicuculline and phaclofen, respectively.), but was not affected by L-arginine-nitric oxide, serotonin, adrenalin and the opioid systems [64].

\section{Anti-implantation activity}

Petroleum ether extracts of $A$. capillus and isoadiantone (22) were reported to be active as inhibitors of postcoital implantation in rats [38].

\section{Antimicrobial activity}

The methanol extract of $A$. capillus-veneris, $A$. peruvianum, $A$. venustum and $A$. caudatum have been tested for their antimicrobial activity against five Gram positive, six Gram negative (including multiresistant Staphylococcus aureus) bacterial and eight fungal strains using standard microdilution assay. Maximum activity was exhibited by $A$. venustum followed by $A$. capillus-veneris, $A$. peruvianum and $A$. caudatum. The extract of $A$. capillus-veneris had very low MIC value $(0.48 \mu \mathrm{g} / \mathrm{mL})$ against Escherichia coli, whereas $A$. venustum extract activity against Aspergillus terreus showed an MIC of 0.97 $\mu \mathrm{g} / \mathrm{mL}$. Total phenolic constituents of $A$. venustum, $A$. capillus-veneris, $A$. peruvianum and $A$. caudatum were $0.81,0.83,0.71$ and $0.52 \% \mathrm{w} / \mathrm{w}$ (gallic acid equivalent), respectively, implying that the observed activity may be related to the content of phenolics [65].

Pradeep et al reported that aqueous and alcohol extracts of $A$. capillus-veneris and $A$. incisum were effective against $A$. tumefaciens; aqueous and alcohol extracts of $A$. capillus-veneris and $A$. lunulatum against E. coli and S. typhi; alcohol extract of $A$. incisum against Salmonella arizonae; aqueous and alcohol extracts of $A$. capillusveneris and $A$. incisum, and alcohol extract of $A$. lunulatum against $S$. aureus [66].

The methanol extract of $A$. trapiziforme inhibited the growth of Bacillus megaterium and Staphylococcus aureus B-43-5. Older plants showed more pronounced activity than 
young ones and fertile fronds had greater activity than vegetative ones [67].

Using disk susceptibility tests, the antibacterial activity of adiantone (23),

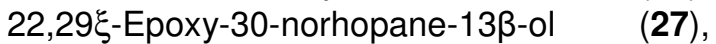
fern-9(11)-en-28-ol (30), fern-9(11)-en-25-oic acid (31), fern-9(11)-en-6 $\alpha$-ol (33), fern-9(11)ene (37), filicenol $B(60)$ and 6-oxofern-9(11)ene were assayed against Gram negative bacteria Escherichia coli (ATCC 25922), Pseudomonas aeruginosa (ATCC 25619), Salmonella typhi (ATCC 23564) and Gram positive bacteria Bacillus sphaericus (ATCC 14577), Bacillus subtilis (ATCC 6051), and Staphylococcus aureus (ATCC 9144) [39]. Compounds 23, 31, and 37 were highly active against $S$. typhi and moderately active against $P$. aeruginosa, while compound 27 showed moderate activity against $S$. typhi. The other compounds did not show significant activity against the tested bacterial strains. Interestingly, Gram negative bacteria, except $E$. coli, were highly susceptible to compounds 23, 31 and $\mathbf{3 7}$ and comparable with the positive control, kanamycin[39].

Alcohol extracts of the rhizome of $A$. capillusveneris effectively inhibited the proliferation and metabolism activity of rifampicin-resistant pulmonary tuberculosis cells [68].

\section{Antiviral activity}

Using vesicular stomatitis virus in monkey cell cultures as test organism, the extracts of A. capillus-veneris was found to exhibit antiviral activity [69].

\section{Agglutinating activity}

Lectin from the leaves of $A$. flabellulatum had a characteristic of glycoproteins, exihibiting agglutinating activity on rabbit erythrocytes, as well as human erythrocytes of $A, B$, or $O$ groups, but had no activity on turtle erythrocytes. It agglutinated cells of unicellular alga (Chlorella pyrenoidosa), natural or heat-treated cells of yeast (Saccharomyces cerbvisiae) and heat-treated cells of Bacillus subtilis [70]. Its' highest agglutining activity on chicken's red blood cell reached $2^{10}$. In addition, it was specific for not only some marine algae, as well as bacterial, yeast and tumor cells but also for two species of plant harmful germ and bacteria, Helminthosporium turcicum and Pseudomonas solanacoarum [71].

\section{Insect-molting hormone activity}

Leaf material from 64 New Zealand ferns was examined for insect molting hormone activity by using the housefly larvae for bioassay. Activity was found in most species including the genera Adiantum [72].

\section{Other activities}

Total flavonoids from $A$. capiuaris-veneris showed high scavenging activity on hydroxyl radicals [73]. El-Tantawy et al determined the antidiabetic and diuretic effects of the alcohol and aqueous extracts of $A$. capillus-veneris as well as the isolated mucilage [55]. Melos et al evaluated the allelopathic potentials of the crude ethanol extract of $A$. tetraphyllum and its fractions against Lactuca sativa (lettuce) and Allium cepa (onion) seeds [3]. The average time of germination of lettuce and onion seeds, when subjected to the crude ethanol extract as well as hexane and AcOEt fractions of $A$. tetraphyllum, respectively, at a concentration of $1000 \mathrm{mg} / \mathrm{L}$, was significantly $(p<0,05)$ longer than that for the control.

\section{CONCLUSION}

Chemical studies on Adiantum species have revealed that the typical constituents of this genus are terpenoids and flavonoids. Among them, some exhibit strong bioactivities, especially analgesic, antinociceptive, antiimplantation, and antimicrobial activities. Further phytochemical and biological studies should be carried out on this genus in order to elucidate their active principles and mechanisms of action of the active constituents. 


\section{ACKNOWLEDGEMENT}

The work was supported by a grant (No. 2005DFA30670) for international collaborative research by Ministry of Science and Technology, China and a grant (No. 2009CC018) from Yunnan Province of China for basic research in social development.

\section{REFERENCES}

1. Delectis Flora Reipublicae Popularis Sinicae Edita, Flora Reipublicae Popularis Sinicae, Tomus 3(1), Beijing, China, Science Press, 1990; pp 173-214.

2. Wu CY. Outline of New China Herbals, Vol. 3, Shanghai, China, Shanghai Press of Science and Technology, 1990, pp 664-668.

3. Melos JLR, Silva LB, Peres MTLP, Mapeli AM, Faccenda O, Anjos HH, Torres TG, Tiviroli SC, Batista AL, Almeida FGN, et al. Chemical composition and evaluation of allelopathic potentials of Adiantum tetraphyllum Humb. \& Bonpl. ex. willd (Pteridaceae). Quim Nova, 2007; 30: 292-297.

4. Gupta M, Bagchi A, Roy SK, Ray AB, Chemical constituents of a member of Adiantum caudatum complex. J Indian Chem Soc, 1990; 67: 86-88.

5. Rangaswami $S$, lyer RT. Chemical examination of Adiantum venustum. Curr Sci, 1967; 36: 8889.

6. Hasegawa M, Akabori Y. Flavonoid pattern in Pteridaceae. I. Flavonoid glycosides obtained from the fronds of Adiantum aethiopicum and A. monochlamys. Shokubutsugaku Zasshi, 1968; 81: 469-472.

7. Akabori $Y$, Hasegawa M. Flavonoid pattern in the pteridaceae. II. Flavonoid constituents in the fronds of Adiantum capillus-veneris and $A$. cuneatum. Shokubutsugaku Zasshi, 1969; 82: 294-297.

8. Imperato F. New phenolic glycosides in the fern Adiantum capullis-veneris L. Chem Ind, 1982; (23): 957-958.

9. Murakami T, Wada H, Tanaka N, Kido T, lida H, Saiki $Y$, Chen CM. Chemical and chemotaxonomical studies of Filices. LXV. A few new flavonoid glycosides. (2). Yakugaku Zasshi, 1986; 106: 982-988.

10. Imperato F. A new acylated flavonol glycoside from the fern Adiantum capillus-veneris. Chem Ind, 1982; (16): 604..

11. Akabori Y. Flavonoid pattern in the Pteridaceae IV. Seasonal variation of the flavonoids in the fronds of Adiantum monochlamys. Bot Mag, 1978; 91: 137-139.

12. Imperato F. Kaempferol 3-sulfate in the fern Adiantum capillus-veneris. Phytochemistry, 1982; 21: 2158-2159.
13. Nung VN, Bezanger-Beauquesne L, Torck $M$. Characterization of flavonoids. Plant Med Phytother, 1971; 5: 177-187.

14. Wollenweber E. Some new external flavonoids from American ferns. Flora, 1979; 168: 138-145.

15. Nakane $T$, Maeda $Y$, Ebihara $H$, Arai $Y$, Masuda $K$, Takano A, Ageta H, Shiojima K, Cai SQ, Abdel-Halim OB. Fern constituents: Triterpenoids from Adiantum capillus-veneris. Chem Pharm Bull, 2002; 50: 1273-1275.

16. Nakane T, Arai $Y$, Masuda K, Ishizaki Y, Ageta H, Shiojima K. Fern constituents: six new triterpenoid alcohols from Adiantum capillusveneris. Chem Pharm Bull, 1999; 47: 543-547.

17. Shiojima K, Ageta H. Fern constituents: triterpenoids isolated from the leaves of Adiantum edgeworthii. Structures of 19hydroxyadiantone and fern-9(11)-en-25-oic acid. Chem Pharm Bull, 1994; 42: 45-47.

18. Shiojima $K$, Arai $Y$, Kasama $T$, Ageta H. Fern constituents: triterpenoids isolated from the leaves of Adiantum monochlamys. Filicenol $A$, filicenol $B$, isoadiantol $B$, hakonanediol and epihakonanediol. Chem Pharm Bull, 1993; 41: 262-267.

19. Ageta $H$, Iwata $K$, Natori S. Fern constituents. Adianene, filicene, 7-fernene, isofernene, and diploptene. Triterpenoid hydrocarbons isolated from Adiantum monochlamys. Tetrahedron Lett, 1964; 5: 3413-3418.

20. Tsuzuki K, Ohashi A, Arai Y, Masuda K, Takano A, Shiojima K, Ageta H, Cai SQ. Triterpenoids from Adiantum caudatum. Phytochemistry, 2001; 58, 363-367.

21. Hayata S, Rahmana A, Choudhary MI, Khan KM, Latif $\mathrm{H}$, Bayer $\mathrm{E}$. Two new triterpenes from fern Adiantum incisum. Z Naturforsch, 2002; 57b: 233-238.

22. Shiojima K, Arai Y, Nakane T, Ageta H, Cai SQ. Fern constituents: Adiantum cuneatum. III. Four new triterpenoids, 4,23-bisnor-3,4-secofilic5(24)-en-3-al, 4,23-bisnor-3,3-dimethoxy-3,4secofilic-5(24)-ene, 7,25-epoxyfern-9(11)-en-8ol and 7,8-epoxyfernan-25-ol. Chem Pharm Bull, 1997; 45: 1608-1610.

23. Shiojima K, Sasaki Y, Ageta H. Fern constituents: triterpenoids isolated from the leaves of Adiantum pedatum. 23-Hydroxyfernene, glaucanol $A$ and filicenoic acid. Chem Pharm Bull, 1993; 41: 268-271.

24. Brahmachari G, Chatterjee D. Triterpenes from Adiantum lunulatum. Fitoterapia, 2002; 73 : 363-368.

25. Abdel-Halim OB, Ibraheim ZZ, Shiojima K. Oleanane triterpenes from Adiantum capillus-veneris growing in Egypt. Alex J Pharm Sci, 2002; 16: 87-92.

26. Mukherjee KS, Mondal S, Sohel SMA, Mukherjee $P$, Chatterjee $D$, Brahmachari $G$. A new triterpene from Adiantum lunulatum Burm. Indian $J$ Chem, 2003; 42B: 2665-2667.

27. Mukherjee KS, Brahmachari G, Chatterjee D, Mukherjee $P$. Triterpene from Adiantum 
Iunulactum. J Indian Chem Soc, 2001; 78: 267-268.

28. Shiojima $K$, Arai $Y$, Nakane $T$, Ageta H. Fern constituents: Adiantum cuneatum. I. Three new triterpenoids, glaucanol $B$ acetate, 7,25epoxyfern-8-ene and 25-norfern-7-en-10-yl formate. Chem Pharm Bull, 1997; 45: 636-638.

29. Ageta H, Shiojima $K$, Arai Y. Fern constituents: neohopene, hopene-II, neohopadiene, and fernadiene isolated from Adiantum species. Chem Commun, 1968; (18): 1105-1107.

30. Shiojima $K$, Arai $Y$, Nakane $T$, Ageta H. Fern constituents: Adiantum cuneatum. II. Six new triterpenoids, neohop-18-en-12-ol, 13epineohop-18-en-12-ol, neohop-13(18)-en-19ol, fern-7-en-25-ol, fern-9(11)-en-25-ol, and adian-5-en-25-ol. Chem Pharm Bull, 1997; 45: 639-642.

31. Zaman A, Prakash A, Berti F, Bottari B, Macchia B, Marsili A, Morelli I. New nortriterpenoid ketol from two Adiantum species. Tetrahedron Lett, 1966; 7: 3943-3947.

32. Nguyen HD, Phan VK, Chau VM, Tran TH, Tran TH, Choudhary MI. Terpenoids from Adiantum emarginatum. Tap Chi Hoa Hoc, 2008; 46: 229-233.

33. Ageta $H$, Iwata $K$, Arai $Y$, Tsuda $Y$, Isobe $K$, Fukushima S. Fern constituents. Hydroxyadiantone and oxohakonanol isolated from Adiantum monochlamys. Tetrahedron Lett, 1966; 7: 5679-5684.

34. Hussain A, Siddiqui HL, Rashid R, Khan KM, Parvez $M$. Hexamethyleicosahydro- $1 \mathrm{H}$ cyclopenta[a]chrysen-3-yl)-1-ethanone. Acta Crystallogr, 2008; E64: o723.

35. Bresciani LFV, Priebe JP, Yunes RA, Magro JD, Monache FD, Campos FD, Souza MM, Cechinel-Filho V. Pharmacological and phytochemical evaluation of Adiantum cuneatum growing in Brazil. Z Naturforsch, 2003; 58c: 191-194.

36. Kshirsagar MK, Mehta AR. Ferns in Gujarat State (India) for presence of antibacterial substances of ferns. Planta Med, 1972; 22: 386-390.

37. Khosa RL, Wahi AK, Mukherjee AK. Chemical studies on Adiantum caudatum. Curr Sci, 1978; 47: 624.

38. Murthy RSR, Basu DK, Murti VVS. Anti-implantation activity of isoadiantone. Indian Drugs, 1984; 21: 141-144.

39. Reddy VLN, Ravikanth V, Rao TP, Diwan PV, Venkateswarlu $Y$. A new triterpenoid from the fern Adiantum lunulatum and evaluation of antibacterial activity. Phytochemistry, 2001; 56: 173-175

40. Ageta H, Iwata K. Fern constituents. Adipedatol, filicenal, and other triterpenoids isolated from Adiantum pedatum. Tetrahedron Lett, 1966; 7: 6069-6074.

41. Erazo S, Garcia R, Mendez F, Latorre I, Negrete R. Secondary metabolites of Adiantum thalictroides Willd. ex. Schlecht var hirsutum
(Hook et Grev.) de la Sota. Rev Latinoam Quim, 1991; 22: 5-6.

42. Banerjee J, Datta G, Dutta CP, Eguciii T, Fujimoto $Y$, Kakinuma K. Fern-9(11)-en-25-oic acid, a triterpene from Adiantum venustum. Phytochemistry, 1991, 30: 3478-3480.

43. Jankowski CK, Aumelas A, Thuery P, Reyes-Chilpa $R$, Jimenez-Estrada $M$, Barrios $H$, Diaz E. $X$ ray, $1 H / 13 C 2 D$ and $3 D N M R$ studies of the structures of davallene and adipedatol, two triterpenes isolated from American Adiantum capillus-veneris. Pol J Chem, 2004; 78: 389408.

44. Shiojima K, Nakane T, Ageta H, Cai SQ. Fern constituents: two new secofilicane triterpenoids from Adiantum cuneatum. Chem Pharm Bull, 1996; 44: 630-632.

45. Ageta H, Shiojima K, Kamaya R, Masuda K. Fern constituent: naturally occurring adian-5-ene ozonide in the leaves of Adiantum monochlamys and Oleandra wallichii. Tetrahedron Lett, 1978; 19: 899-900.

46. Giancarlo B, Francesco B, Marsili A. Structure and stereochemistry of a triterpenoid epoxide from Adiantum capillus-veneris. Tetrahedron, 1969; 25: 2939-2947.

47. Naseri NG, Ashnagar A, Nia SJ. Isolation and structural determination of the major chemical compounds possibly found in the leaves of maidenhair plant (Adiantum capillus-veneris. L) grown around the city of Dezful, Iran Int J Chem Sci, 2006; 4: 874-880.

48. Alam MS, Chopra N, Ali M, Niwa M. Normethyl pentacyclic and lanostane-type triterpenes from Adiantum venustum. Phytochemistry, 2000; 54: 215-220.

49. Hussain A, Siddiqui HL, Zia-ur-Rehman M, Elsegood MRJ, Khan KM. 4-Hydroxy$4,6 a, 6 b, 9,9,12 a, 14 b-$

heptamethylperhydropicen-3-one hemihydrate isolated from Adiantum incisum. Acta Crystallogr, 2008; E64: 0264.

50. Neeraj C, Sarwar AM, Mohammad A, Masatake N. A new lanostane triterpenic ether from Adiantum venustum. Pharmazie, 2000; 55: 538-539.

51. Neeraj C, Sarwar AM, Mohammad A, Masatake N. Isolation and characterization of two novel triterpenes from Adiantum venustum. Indian $\mathrm{J}$ Chem, 2001; 40B: 350-353.

52. Neeraj C, Sarwar AM, Mohammad A, Masatake N. A novel tirucallane triterpene from Adiantum venustum. Pharmazie, 1997; 52: 412-413.

53. Imperato F. Sulfate esters of hydroxycinnamic acidsugar derivatives from Adiantum capillusveneris. Phytochemistry, 1982; 21: 2717-2718.

54. Cooper-Driver GC, Swain T. Sulfate esters of caffeyland $p$-coumarylglucose in ferns. Phytochemistry, 1976; 14: 2506-2507.

55. El-Tantawy M, El-Sakhawy F, El-Deeb K, Fathy M, Hassan AK. A phytochemical and pharmacological study of Adiantum capillus veneris L. growing in Egypt. Zagazig J Pharm Sci, 1994; 3: 97-103. 
56. Marino A, Elberti MG, Cataldo A. Phytochemical analysis of Adiantum capillus-veneris. Bollettino, 1989; 65: 461-463.

57. Minamikawa T, Yoshida S. Occurrence of quinic acid in the ferns. Shokubutsugaku Zasshi, 1972; 85: 153-155.

58. Sato $N$, Furuya $M$. Isolation and identification of diacylglyceryl-O-4'-(N,N,N-trimethyl)homoserine from the fern Adiantum capillusveneris L. Plant Cell Physiol, 1983; 24: 11131120.

59. Gellerman JL, Schlenk E. Occurrence of arachidonic and related acids in plants. Experientia, 1964; 20: 426-427.

60. Kang WY, Ji ZQ, Wang JM. Composition of the essential oil of Adiantum flabellulatum. Chem Nat Compd, 2009; 45: 575-577.

61. Ji ZQ, He GD, Kang WY. HS-SPME-GC-MS Analysis of the essential oil in common Adiantum edgeworthii. Zhongguo Yaofang, 2008; 19: 2359-2360.

62. Mahran GH, El-Alfy TS, El-Tantawy M, El-Sakhawy F. Chemical constituents of Adiantum capillus veneris, growing in Egypt. Al-Azhar J Pharm Sci, 1994; 13: 1-14.

63. Hussain $M M$, Muthuprasanna $P$, Srinivasarao $T$, Velraj $M$, Shanmugapandian $P$, Suriaprabha $K$. Analgesic and antiinflammatory activity of Adiantum venustum. Res Rev Biosci, 2008; 2: 102-104.

64. De Souza MM, Pereira MA, Ardenghi JV, Mora TC, Bresciani LF, Yunes RA, Delle Monache F, Cechinel-Filho $V$. Filicene obtained from Adiantum cuneatum interacts with the cholinergic, dopaminergic, glutamatergic, GABAergic, and tachykinergic systems to exert antinociceptive effect in mice. Pharmacol Biochem Be, 2009; 93: 40-46.

65. Singh $M$, Singh $N$, Khare $P B$, Rawat AKS. Antimicrobial activity of some important Adiantum species used traditionally in indigenous systems of medicine. $J$ Ethnopharmacol, 2008; 115: 327-329.

66. Pradeep $P$, Leena $P$, Achaleshwar $B$. In vitro antibacterial activity of fronds (leaves) of some important pteridophytes. J Microbiol Antimicrob, 2010; 2: 19-22.

67. Kshirsagar MK, Mehta AR. Ferns in Gujarat State (India) for presence of antibacterial substances of ferns. Planta Med, 1972; 22: 386-390.

68. Tan YY, Xiang YM. Effects of the alcohol extracts from rhizoma Adiantum capillus-veneris on rifampicin-resistant pulmonary tuberculosis cells. J Wuhan Univ Sci Eng, 2003; 16: 79-83.

69. Husson GP, Vilagines $R$, Delaveau $P$. Research into the antiviral properties of some natural extracts. Ann Pharm Fr, 1986; 44: 41-48.

70. $Y u$ P, Zheng $Y$, Liu YR. Characteristics of glycoproteins in Adiantum flabellulatum lectins. $J$ Trop Subtrop Bot, 2004; 12: 57-62.

71. Yu P, Liu YR, Zheng Y. Comparison of cell agglutination and Bacteriostasis of lectins from two Pteridophytes. J Fujian Norm Univ, 2004; 20: 77-81.

72. Russell GB, Fenemore PG. Insect molting hormone activity in some New Zealand ferns. New Zeal J Sci, 1971; 14: 31-35.

73. Lin YR, Ding LJ. Extraction and determination on clearance rate of hydroxyl radicals of flavonoid from Adiantam capillus-veneris. Food Mach; 2008; 24: 63-66. 